\title{
Trade Adjustment and the Composition of Trade*
}

\author{
Christopher J. Erceg, Luca Guerrieri, and Christopher Gust**
}

April 2006

\begin{abstract}
A striking feature of U.S. trade is that both imports and exports are heavily concentrated in capital goods and consumer durables. However, most open economy general equilibrium models ignore the marked divergence between the composition of trade flows and the sectoral composition of U.S. expenditure, and simply posit import and exports as depending on an aggregate measure of real activity (such as domestic absorption). In this paper, we use a SDGE model (SIGMA) to show that taking account of the expenditure composition of U.S. trade in an empirically-realistic way yields implications for the responses of trade to shocks that are markedly different from those of a "standard" framework that abstracts from such compositional differences. Overall, our analysis suggests that investment shocks, originating from either foreign or domestic sources, may serve as an important catalyst for trade adjustment, while implying a minimal depreciation of the real exchange rate.
\end{abstract}

Keywords: SDGE model, open-economy macroeconomics

JEL Codes: F41, F17

\footnotetext{
* The authors thank Hilary Croke for excellent research assistance. We also thank Dale Henderson and Paolo Pesenti (our discussant) for helpful discussions, participants at a joint FRB-ECB-IMF conference held at the Federal Reserve Board in December 2005, and seminar participants at the Bureau of Economic Analysis and George Washington University. The views expressed in this paper are solely the responsibility of the authors and should not be interpreted as reflecting the views of the Board of Governors of the Federal Reserve System or of any other person associated with the Federal Reserve System.

** Corresponding Author: Christopher Gust, Telephone 202-452-2383, Fax 202-872-4926. Email addresses: christopher.erceg@frb.gov, luca.guerrieri@frb.gov, and christopher.j.gust@frb.gov.
} 


\section{Introduction}

A striking feature of U.S. trade is that both imports and exports are heavily concentrated in capital goods and consumer durables, with roughly three-quarters of U.S. non-fuel imports and exports appearing to fall into these categories. This contrasts with the relatively low production share of the capital goods and consumer durables sectors in the U.S. economy of under 20 percent. But despite the marked divergence between the composition of trade flows and the sectoral composition of U.S. production, most open economy models simply posit imports and exports as depending on an aggregate measure of activity such as real GDP or domestic absorption (as well as on relative prices). ${ }^{1}$

In this paper, we show that a modeling framework that takes account of the expenditure composition of U.S. trade in an empirically-realistic way yields implications for the responses of trade to shocks that are markedly different from those of a "standard" framework that abstracts from such compositional differences. Our methodology consists in contrasting the implications of alternative versions of an open economy SDGE model ("SIGMA") that embed different trade specifications. ${ }^{2}$ In the version adopting a commonly-used trade specification, the activity variable driving real imports is simply domestic absorption, while exports depend on foreign absorption. We refer to this version as the absorption-based trade (AT) specification. By contrast, our benchmark version of SIGMA posits separate behavioral equations for trade in nondurable consumer goods and for trade in investment goods, where the latter includes both consumer and producer durables (i.e., capital goods). These behavioral equations are derived from underlying technologies for producing final consumer and investment goods that differ by allowing the production

\footnotetext{
${ }^{1}$ Examples of studies that make imports depend on absorption are: Backus, Kehoe, and Kydland (1994), Chari, Kehoe, and McGrattan (2002), Laxton and Pesenti (2003).

${ }^{2}$ An extended description of the model and its properties with respect to a wide range of shocks is given in Erceg, Guerrieri, and Gust (2006).
} 
of investment goods to be more import-intensive. We refer to this version as the disaggregated trade (DT) specification.

As a prelude to our model simulations, we compare the ability of the alternative specifications to account for the historical evolution of U.S. imports. Our analysis provides empirical support for our DT specification, which tracks imports remarkably well, including during periods of large cyclical swings in imports. By contrast, while the fitted import series implied by the AT specification also shows strong comovement with the historical series, it is much less volatile. Intuitively, the improved fit of the DT specification reflects that investment receives a much higher weight in determining imports. Overall, our empirical analysis suggests that investment swings might play a considerably more prominent role in determining trade flows than implied by traditional absorption-based (or output-based) trade models.

We then use our SIGMA model to examine its responses to several domestic and foreign shocks under the alternative trade specifications. We show that the differences in implications across the alternative trade specifications are particularly large for shocks which exert disparate effects on consumption and investment spending either at home or abroad. Examples include shocks that affect the rate of return on investment ("investment shocks"), and preference shocks for consumption ("consumption shocks"). From an intuitive perspective, the activity variable driving imports and exports in the disaggregated trade specification weights consumption and investment by their share in trade, rather than by their share in absorption: this implies an effective weight on investment in the import and export demand functions that is several times larger than in the absorption-based trade specification.

A key result derived from our benchmark DT trade specification is that a shock that raises foreign investment by one percentage point of GDP has a much larger effect on the U.S. trade balance than a shock that boosts foreign consumption by one 
percentage point of GDP. Moreover, the foreign investment shock is associated with a larger export expansion, and much smaller depreciation of the real exchange rate. This contrasts sharply with the implications of the absorption-based trade model, in which the alternative shocks have broadly similar effects on the real exchange rate, the trade balance, and its components.

The reason why the foreign investment and consumption shocks have similar effects in the standard absorption-based trade model is that they have commensurate effects on foreign absorption; although the shocks have very different implications for the composition of absorption between investment and consumption, only total absorption matters for trade flows. By contrast, in our benchmark DT specification, the foreign investment shock induces a much larger improvement in real exports and the nominal trade balance than the foreign consumption shock because of the higher effective weight of foreign investment spending in the U.S. export demand equation. The stronger export stimulus induces domestic real interest rates to rise by more than in the case of the foreign consumption shock, so that the real exchange rate depreciates much less in response to a foreign investment shock than to a foreign consumption shock.

We show that roughly similar results apply when the investment and consumption shocks emanate from the home rather than the foreign economy. Thus, our benchmark DT specification implies that a shock that raises domestic investment by one percentage point of GDP has a much larger effect on the trade balance than a shock that raises domestic consumption by the same fraction of GDP. This contrasts with the absorption-based trade specification, which implies again that the shocks have roughly commensurate effects on the real exchange rate and trade flows.

Overall, our analysis using a disaggregated trade specification suggests that investment shocks, originating from either foreign or domestic sources, may serve as an important catalyst for facilitating adjustment of the trade balance; moreover, a distinctive feature of this channel is that it may be consistent with a relatively 
stable exchange value of dollar. The prominent role that we identify for investment shocks in our analysis would seem to complement the empirical work of Freund (2000) and Croke, Kamin, and Leduc (2005). These authors used an event study methodology examining a large number of historical episodes of trade adjustment in industrial countries, and found that trade adjustment has typically been driven by a large decline in the rate of investment spending, while consumption rates have moved little.

The remainder of this paper is organized as follows. Section 2 presents some stylized facts about the composition of U.S. imports and exports that motivate the trade structure adopted in our benchmark model. These facts are utilized subsequently in the calibration. Section 3 presents our SIGMA model, including the alternative trade specifications, while the calibration and solution methodology is discussed in Section 4. Section 5 compares the ability of the alternative trade specifications to account for the empirical behavior of U.S. imports. Section 6 contrasts model responses to an array of domestic and foreign shocks across the alternative trade specifications. Section 7 concludes.

\section{The Composition of U.S. Trade}

Table 1 examines the composition of U.S. nonfuel imported goods in 2004. The underlying data used to construct the table is from the U.S. Bureau of Economic Analysis (on a balance-of-payments basis), although it has been reorganized to correspond more closely to the coarser disaggregation adopted in our theoretical model. In particular, we divide nominal nonoil imports into four categories, including consumer nondurable goods, consumer durables, capital goods, and non-energy industrial supplies utilized in producing durable goods (either for households or firms). The major components of the first three of these categories are derived fairly straightforwardly from the corresponding BEA data, aside from the estimate of nonenergy industrial 
supplies used in producing nondurable consumer goods (item 1d). Our estimate of the latter category is derived by assuming that the share of imports of nonenergy industrial goods that are used in producing consumer nondurables is equal to the share of consumer nondurables in total manufacturing production (of about 40 percent).

The table suggests that nearly three-quarters of U.S. goods imports consist of either consumer or producer durable goods, or of industrial supplies used in manufacturing such goods. By contrast, only a little over 25 percent of U.S. goods imports consist of consumer nondurables (including raw materials). While our taxonomy for classifying imports is admittedly imperfect - for example, imports of consumer durables may be somewhat inflated due to extensive cross-border trade in automotive parts - it is unlikely that reasonable alternative breakdowns would markedly affect our results.

Table 2 reports a similar breakdown for U.S. nonfuel goods exports in 2004. Clearly, capital goods are a noticeably larger fraction of U.S. exports than of U.S. imports, while consumer durables are a somewhat smaller fraction of exports. But notwithstanding these differences, nearly three-quarters of U.S. exports consist of either consumer or producer durable goods, or of industrial supplies used in producing such goods - the same fraction as for U.S. imports. Thus, the composition of U.S. imports and exports is heavily oriented towards durable goods, which in our model we interpret broadly as investment goods.

\section{The Model}

This section provides an abbreviated description of a two country version of our SIGMA model, focusing on the alternative trade specifications. A complete description of our benchmark SIGMA model is provided in Erceg, Guerrieri, and Gust (2006). 


\subsection{Firms and Price Setting}

SIGMA incorporates a relatively standard framework with monopolistic competition among intermediate goods-producing firms in order to rationalize stickiness in aggregate prices. Each intermediate-goods producer has an identical CES production function, and rents capital and labor from competitive factor markets. Intermediate goods prices are set in Calvo-style staggered contracts, and producers practice "local currency pricing." Thus, each firm faces a constant probability, $1-\xi_{p}$, of receiving a signal allowing it to optimally adjust its price in the domestic market $\left(P_{D t}(i)\right)$ in each period, and similarly, a constant probability $1-\xi_{p, x}$ of receiving a signal to reset its price in the foreign market $\left(P_{M t}^{*}(i)\right)$. These probabilities are assumed to be independent across firms, time, and countries. For those firms not allowed to re-optimize their price, we follow Christiano, Eichenbaum, and Evans (2001) in assuming that they mechanically adjust their price based on lagged aggregate inflation. This indexation scheme introduces structural inflation persistence into the aggregate pricing equations.

Following a standard approach in the literature, the intermediate goods sold in the domestic market are assembled into a single composite domestic good $Y_{D t}$ by a representative "aggregator." This firm has a CES production function over the intermediate goods $Y_{D t}(i)$ of the Dixit-Stiglitz form, behaves competitively in factor and product markets, and sells the composite domestic good at a price $P_{D t}$. Similarly, there is a representative aggregator in the foreign economy that combines the differentiated home goods into a single foreign import index $M_{t}^{*}$, which it sells at a price $P_{M t}^{*}$.

Production of Consumption and Investment Goods. We consider two alternative specifications for the production of consumption and investment goods. In our benchmark specification of SIGMA, there are different technologies for the production of final consumption and investment goods. Because this leads to a specification in which imports are segmented into consumption and investment goods, with sep- 
arate demand functions for each category of imports, we call this the disaggregated (DT) trade specification. In our alternative specification, we assume that the technology for producing final consumption and investment goods is the same. We call this alternative the absorption-based trade (AT) specification, because import demand depends only on the sum of private consumption and investment, i.e., private absorption.

We begin by describing our benchmark version of the model which uses the DT specification. In this case, we assume that final consumption goods are produced by a representative consumption good distributor, and investment goods are produced by a representative investment goods distributor. Letting $V_{t} \in\left\{C_{t}, I_{t}\right\}$ be the good each type of distributor produces, a representative distributor's production technology is given by:

$$
V_{t}=\left(\omega_{V}^{\frac{\rho_{V}}{1+\rho_{V}}} V_{D t}^{\frac{1}{1+\rho_{V}}}+\left(1-\omega_{V}\right)^{\frac{\rho_{V}}{1+\rho_{V}}}\left(\varphi_{V t} M_{V t}\right)^{\frac{1}{1+\rho_{V}}}\right)^{1+\rho_{V}}
$$

where $V_{D t} \in\left\{C_{D t}, I_{D t}\right\}$ is a distributor's demand for the index of domesticallyproduced goods, $M_{V t} \in\left\{M_{C t}, M_{I t}\right\}$ is a distributor's demand for the index of foreign-produced goods, and $\rho_{V}$ is parameter determining the substitutability of home and foreign goods. The quasi-share parameter $\omega_{V}$ may be interpreted as determining a household's preference for home relative to foreign goods, or equivalently the degree of home-bias in private consumption or investment. Because $\omega_{V}$ can differ depending on whether the final good is a investment or consumption good, this specification allows the import-content of consumption and investment to differ. The term $\varphi_{V t}$ reflects a cost to adjusting imports, which are assumed to be quadratic:

$$
\varphi_{V t}=\left[1-\frac{\varphi_{M_{V}} \omega_{V}}{2}\left(\frac{\frac{M_{V t}}{V_{D t}}}{\frac{M_{V t-1}}{V_{D t-1}}}-1\right)^{2}\right] .
$$

This adjustment cost implies that it is costly to change the share of consumption imports in final consumption, or of investment imports in final investment. It has the attractive feature that the import share of either consumption or investment 
goods is relatively unresponsive in the short-run to changes in the relative price of imported goods, even while allowing the level of imports to jump costlessly in response to changes in overall consumption or investment demand. ${ }^{3}$ Thus, these adjustment costs influence the short-run elasticity of substitution between home and foreign goods. In steady state, adjustment costs on imports are zero and the elasticity of substitution between home and foreign goods is governed exclusively by $\rho_{V}$.

Given the presence of adjustment costs, each type of representative distributor chooses a contingency plan for $V_{D t}$ and $M_{V t}$ to minimize its discounted expected costs of producing the final good $V_{t} \in\left\{C_{t}, I_{t}\right\}$ :

$$
\begin{aligned}
& \min _{V_{D t}, M_{V t}} \widetilde{\mathbb{E}}_{t} \sum_{k=0}^{\infty} \psi_{t, t+k}\left(P_{D t+k} V_{D t+k}+P_{M t+k} M_{V t+k}\right) \\
& +P_{V t}\left[V_{t}-\left(\omega_{V}^{\frac{\rho_{V}}{1+\rho_{V}}} V_{D t}^{\frac{1}{1+\rho_{V}}}+\left(1-\omega_{V}\right)^{\frac{\rho_{V}}{1+\rho_{V}}}\left(\varphi_{V t} M_{V t}\right)^{\frac{1}{1+\rho_{V}}}\right)^{1+\rho_{V}}\right] .
\end{aligned}
$$

The distributor sells $V_{t}$ to households at a price $P_{V t} \in\left\{P_{C t}, P_{I t}\right\}$ so that there is a different price for consumption and investment, reflecting the different technologies for aggregating these goods.

In the alternative AT specification, there is effectively only one final good $\left(A_{t}\right)$ that may be used for consumption or investment, (i.e., $A_{t} \equiv C_{t}+I_{t}$, noting that $A_{t}$ can be interpreted as private absorption). Accordingly, there is effectively a single distributor which combines its purchases of the domestically-produced goods with imported goods to produce final goods $A_{t}$ according to

$$
A_{t}=\left(\omega_{A}^{\frac{\rho_{A}}{1+\rho_{A}}} A_{D t}^{\frac{1}{1+\rho_{A}}}+\left(1-\omega_{A}\right)^{\frac{\rho_{A}}{1+\rho_{A}}}\left(\varphi_{A t} M_{t}\right)^{\frac{1}{1+\rho_{A}}}\right)^{1+\rho_{A}}
$$

where $A_{D t}$ denotes the distributor's demand for the domestically-produced good and $M_{t}$ denotes the distributor's demand for imports. The quasi-share parameter

\footnotetext{
${ }^{3}$ Hooper, Johnson, and Marquez (2000) find that the short-run trade price elasticity is significantly smaller than the long-run elasticity in their study using aggregate data. This is qualitatively consistent with the results of industry studies as surveyed by McDaniel and Balistreri (2003).
} 
$\omega_{A}$ determines the degree of home bias in private absorption, and $\rho_{A}$ determines the elasticity of substitution between home and foreign goods in the long run. In the short run, this elasticity is lower, because we allow for adjustment costs $\varphi_{A t}$ :

$$
\varphi_{A t}=\left[1-\frac{\varphi_{M_{A}} \omega_{A}}{2}\left(\frac{\frac{M_{t}}{A_{D t}}}{\frac{M_{t-1}}{A_{D t-1}}}-1\right)^{2}\right] .
$$

Note that the adjustment costs in this case depend on the ratio of total consumption to total absorption, rather than depending on each of the components of absorption separately.

Distributors of $A_{t}$ solve an intertemporal cost minimization problem analogous to the consumption and investment distributors of the DT specification. The distributor sells its good to households at price $P_{A t}$ which may be interpreted as the price of consumption or investment, since in this case $P_{A t}=P_{C t}=P_{I t}$.

\subsection{Households and Wage Setting}

We assume that there are two types of households: households that maximize utility subject to an intertemporal budget constraint (FL households, for "forwardlooking"), and the remainder that simply consume their after-tax disposable income (HM households, for "hand-to-mouth" households). We denote the share of FL households by $\varsigma$ and the share of HM households by $1-\varsigma$.

We consider first the problem faced by FL households. The utility functional of a representative member of FL household $h$ is

$$
\begin{aligned}
& \widetilde{\mathbb{E}}_{t} \sum_{j=0}^{\infty} \beta^{j}\left\{\frac{1}{1-\sigma}\left(C_{t+j}(h)-\varkappa C_{t+j-1}^{O}-\nu_{c t}\right)^{1-\sigma}+\right. \\
& \left.\frac{\chi_{0}}{1-\chi}\left(1-N_{t+j}(h)\right)^{1-\chi}+\frac{\mu_{0}}{1-\mu}\left(\frac{M B_{t+j+1}(h)}{P_{C t+j}}\right)^{1-\mu}\right\}
\end{aligned}
$$

where the discount factor $\beta$ satisfies $0<\beta<1$. As in Smets and Wouters (2003), we allow for the possibility of external habits, where each household member at 
date $t$ cares about its consumption relative to the lagged consumption per capita of FL households, $C_{t-1}^{O}$. The period utility function depends on an each member's current leisure $1-N_{t}(h)$, his end-of-period real money balances, $\frac{M B_{t+1}(h)}{P_{C t}}$, and a preference shock, $\nu_{c t}$. The preference shock follows an exogenous first order process with a persistence parameter of $\rho_{v}$.

These households allocate their income optimally between consumption goods, investment goods, and financial assets. The effective price of a new investment good consists of the purchase price scaled up by a quadratic adjustment cost term, i.e. $P_{I t}\left(1+\phi_{I t}(h)\right)$, where we follow Christiano, Eichenbaum, and Evans (2005) in specifying the adjustment cost $\phi_{I t}(h)$ as depending on the change in the level of gross investment from the previous period:

$$
\phi_{I t}(h)=\frac{1}{2} \phi_{I} \frac{\left(I_{t}(h)-I_{t-1}(h)\right)^{2}}{I_{t-1}(h)} .
$$

Investment in physical capital augments the household's capital stock $K_{t+1}(h)$ according to a linear transition law of the form:

$$
K_{t+1}(h)=(1-\delta) K_{t}(h)+I_{t}(h)
$$

where $\delta$ is the depreciation rate of capital.

Households also choose optimal portfolios of financial assets, which include domestic money balances, government bonds, state-contingent domestic bonds, and a non-state contingent foreign bond. We follow Turnovsky (1985) by assuming that households in the home country pay an intermediation cost when purchasing foreign bonds, which ensures the stationarity of net foreign assets.

Household income consists of after-tax capital income, wage income, and an aliquot share of firm profits, minus net lump-sum taxes paid to the government. Capital rental income is taxed at the stochastic rate $\tau_{K t}$, but is partly offset by a depreciation writeoff of of $P_{I t} \tau_{K t} \delta$ per unit of capital (the capital tax rate is assumed to follow a first order autoregression with persistence parameter $\rho_{K}$ ). Households 
earn wage income by renting their labor to firms. We assume that each household is a monopolistic competitor in the labor market, and sets its nominal wage in Calvostyle staggered contracts that are analogous to the price contracts discussed earlier. The probability that members of a household receive a signal which allows them to optimally reset their nominal wage is $1-\xi_{w}$. The remaining $\xi_{w}$ households that do not receive such a signal simply adjust their wage mechanically to aggregate wage inflation in the previous period.

Finally, we consider the determination of consumption and labor supply of the hand-to-mouth (HM) households. A typical member of a HM household simply equates his nominal consumption spending to his current after-tax disposable income, which consists of labor income minus net lump-sum government taxes. The HM households are assumed to set their wage each period equal to the average wage of the forward-looking households. Since HM households face the same labor demand schedule as the forward-looking households, each HM household works the same number of hours as the average forward-looking household.

\subsection{Monetary and Fiscal Policy}

We assume that the central bank follows an interest rate reaction function similar in form to the historical rule estimated by Orphanides and Wieland (1998) over the Volcker-Greenspan period. Thus, the short-term nominal interest rate is adjusted so that the ex post real interest rate rises when inflation exceeds its constant target value, or when output growth rises above some target value:

$$
i_{t}=\gamma_{i} i_{t-1}+\bar{r}+\bar{\pi}_{t}+\gamma_{\pi}\left(\pi_{t}^{(4)}-\bar{\pi}\right)+\gamma_{y}\left(y_{t}-y_{t-4}-g_{y}\right)+\epsilon_{i t}
$$

In the above, $i_{t}$ is the annualized nominal interest rate, $\pi_{t}^{(4)}$ is the four-quarter inflation rate of the GDP deflator (i.e., $\pi_{t}^{(4)}=\sum_{j=0}^{3} \pi_{t-j}$ ), $\bar{r}$ and $\bar{\pi}$ are the steady-state real interest rate and the central bank's constant inflation target (both expressed at annual rate). Also, $y_{t}-y_{t-4}$ is the four-quarter growth rate of output, and $g_{y}$ is 
its corresponding steady state value.

Some of the domestically-produced good is purchased by the government, although government purchases makes no direct contribution to household utility. Government purchases are assumed to be a constant fraction of output $\bar{g}$.

Government revenue consists of income from labor and capital taxes (net of the depreciation writeoff), seignorage income, and revenue from lump-sum taxes (net of transfers). The government issues bonds to finance the difference between government revenue and expenditure, where the latter consists entirely of government purchases. Lump-sum taxes (as a share of GDP) are adjusted both in response to deviations of the government debt/GDP ratio from a target level (with a coefficient $\nu_{1}$ ) and to the change in that ratio (with a coefficient $\nu_{2}$ ); this allows the government to satisfy its intertemporal resource constraint.

\subsection{Resource Constraints}

The home economy's aggregate resource constraint can be written as:

$$
Y_{D t}=C_{D t}+I_{D t}+G_{t}+\phi_{I t},
$$

Thus, the composite domestically-produced good $Y_{D t}$ (net of investment adjustment costs $\left.\phi_{I t}\right)$ can be used as an input into final consumption or investment goods (or into final absorption in the AT specification), or can be used directly to satisfy government demand. Moreover, since each individual intermediate goods producer can sell its output $Y d_{t}(i)$ either at home or abroad (which is in turn "bundled" by the respective aggregator), there are also a continuum of resource constraints that apply at the firm level.

\section{Solution Method and Calibration}

Because the level of technology is non-stationary due to deterministic growth in technology (at a common rate of $e^{\left(g_{z} t\right)}$ in each country), real variables are also non- 
stationary. Accordingly, prior to solving the model, we scale real variables in each country by this deterministic trend. Nominal variables are scaled to account both for growth in the corresponding real variables, and for the steady state inflation rate.

We solve the model by log-linearizing the equations (specified in terms of the transformed variables) around the steady state associated with common growth rates of technology in the two countries. To obtain the reduced-form solution of the model, we use the numerical algorithm of Anderson and Moore (1985), which provides an efficient implementation of the method proposed Blanchard and Kahn (1980).

\subsection{Calibration of Parameters}

The model is calibrated at a quarterly frequency. The values of key parameters are presented in Table 3. Given that we provide a description of the parameters associated with household preferences, technology, and monetary and fiscal policy in Erceg, Guerrieri, and Gust (2006), our present discussion focuses only on the parameters affecting trade flows under the alternative trade specifications considered.

For both specifications of import demand, the steady-state ratio of aggregate imports to GDP is 0.12 . In the AT specification we choose $\omega_{A}=0.15$ to be consistent with this import share. In the DT specification, we set $\omega_{C}=0.052$ and $\omega_{I}=0.36$, so that roughly five percent of consumption goods and 36 percent of investment goods are comprised of imports. These choices for $\omega_{C}$ and $\omega_{I}$ are consistent with the evidence presented in Table 1 (and GDP expenditure data from the national income accounts). We choose the population levels so that the home country constitutes about 25 percent of world output. This implied an import (or export) share of output of the foreign country of about 3 percent. Because the foreign country is assumed identical to the home country except in its size, in the AT specification, $\omega_{A}^{*}=0.05$. In the DT specification we set $\omega_{C}^{*}=0.01$ and $\omega_{I}^{*}=0.07$, both consistent 
with the evidence presented in Table 2 .

We assume that the trade-price elasticities of import demand are the same across the two specifications. In particular, we set $\rho_{C}=\rho_{I}=\rho_{A}=2$, consistent with a long-run price elasticity of demand for imported consumption and investment goods of 1.5. Our setting of the adjustment cost parameters $\varphi_{M_{C}}=\varphi_{M_{I}}=\varphi_{M_{A}}=15$ implies a price-elasticity of slightly below unity after four quarters.

\section{Alternative Trade Specifications: Empirical Fit}

In this section, we examine the ability of the DT specification to account for the empirical behavior of U.S. real nonoil imports, and compare its performance to the AT specification. In particular, we construct empirical counterparts to the activity and relative import price variables that drive real imports under each trade specification, and assess how closely the fitted series track data on real U.S. imports. One complication in carrying out this exercise is that our forward-looking trade adjustment cost specifications require making additional parametric assumptions about the evolution of the relative price of imports. Neverthless, as we argue below, the difference between specifications is driven almost exclusively by the alternative activity variables, and do not hinge on the particular features of the adjustment cost specification.

The log-linearized behavioral equation determining import demand under the AT specification may be expressed as:

$$
E_{t} \tilde{x}_{t+1}-\left(1+\frac{1}{\beta}+\frac{1}{\beta \varphi_{M_{A}} \epsilon_{A}}\right) \tilde{x}_{t}+\frac{1}{\beta} \tilde{x}_{t-1}=\frac{1}{\beta \varphi_{M_{A}}} \tilde{\psi}_{t}
$$

We use tildes to indicate the logarithmic deviation of a variable from steady state. In this equation, $x_{t}$ is the ratio of real imports to private absorption (i.e., $\left.\tilde{x}_{t}=\tilde{M}_{t}-\tilde{A}_{t}\right), \psi_{t}$ is the ratio of the import price to the absorption price deflator, and $\epsilon_{A}=\frac{1+\rho_{A}}{\rho_{A}}$ is the (long-run) price elasticity of import demand. To derive a 
relationship that does not involve future expectations, we assume that the relative price of imports follows an exogenous stochastic process, which for simplicity we specify to be a first order autoregression with persistence parameter $\rho_{\psi}$. Under this assumption, the difference equation can be solved and expressed in the form:

$$
\tilde{M}_{t}=\tilde{A}_{t}-\frac{\lambda}{\varphi_{M_{A}}\left(1-\beta \lambda \rho_{\psi}\right)(1-\lambda L)} \tilde{\psi}_{t}
$$

Thus, real imports depend on private absorption $\left(A_{t}\right)$, and on a distributed lag of the ratio of the import price to the private absorption deflator $\left(\psi_{t}\right)$. The distributed lag polynomial on import prices, which dies out at the rate $\lambda$ (our calibration implies $\lambda=0.77$ ), arises due to the presence of trade adjustment costs. The sum of the lag coefficients equals 1.5, the long-run trade price elasticity. As discussed in Section 3, our specification of adjustment costs implies that imports react immediately to changes in real activity (i.e., private absorption under the AT specification), but only gradually to relative price changes.

Given that our calibration for the DT specification imposes trade adjustment costs and the trade price elasticities for both consumption and investment imports that are identical to the AT specification, the equation for aggregate imports under the DT case can be expressed in a symmetric form:

$$
\tilde{M}_{t}=\tilde{A}_{t}^{D T}-\frac{\lambda}{\varphi_{M_{A}}\left(1-\beta \lambda \rho_{\psi}\right)(1-\lambda L)} \tilde{\psi}_{t}^{D T}
$$

The only differences are that the DT activity measure $A_{t}^{D T}$ replaces absorption $A_{t}$ as the activity variable, and that the relative import price measure $\psi_{t}^{D T}$ replaces $\psi_{t}$. The activity variable under the DT specification weights consumption and investment by their respective share in total imports, that is:

$$
\tilde{A}_{t}^{D T}=\left(\frac{M_{C}}{M}\right) \tilde{C}_{t}+\left(\frac{M_{I}}{M}\right) \tilde{I}_{t}
$$

where we denote steady state values by omitting time subscripts. This contrasts with the AT specification, in which the activity variable $A_{t}$ weights these components by 
their share in total private absorption:

$$
\tilde{A}_{t}=\left(\frac{C}{A}\right) \tilde{C}_{t}+\left(\frac{I}{A}\right) \tilde{I}_{t}
$$

Thus, using our calibration, investment receives a weight of $3 / 4$ in the activity variable driving imports under the DT specification, which is more that three times the weight it receives under the AT specification. Similarly, the relative price term $\psi_{t}^{D T}$ is the ratio of the import price to a 'DT absorption price' that weights the consumption and investment deflators by the share of each component in total U.S. nonoil imports.

We next examine how the specifications (12) and (13) fit the historical behavior of U.S. real nonoil imports over the 1975:1-2005:3 period. Beginning with the AT specification, we use data on real private absorption and the ratio of the price of nonoil imports to the absorption deflation (i.e., $\psi_{t}$ in equation $(12)$ ) to construct a fitted real import series. The (log of the) HP-filtered series is plotted in Figure 1A against HP-filtered U.S. real nonoil imports. The figure also plots the relevant activity variable, HP-filtered private absorption, to help assess the relative importance of the activity and relative price terms in determining real imports (thus, the contribution of the distributed lag of the relative import price is simply the difference between the fitted series, the dashed-dotted red line, and private absorption, the dashed green line).

While the fitted real import series under the AT specification exhibits strong positive comovement with the corresponding data, the former is clearly much less volatile. The relative smoothness in the fitted import series reflects that private absorption - the activity variable - is much less volatile than real imports, and that relative prices make a fairly small contribution to the volatility of the fitted series. To help understand this small price contribution, Figure 2 plots the ratio of the price of imports to the absorption price, as well as real imports (both series are again HP-filtered). Clearly, real imports exhibit much more volatility than the relative import price over the entire sample period, with the disparity even more 
pronounced since the early 1990s. ${ }^{4}$ Thus, even assuming that trade price elasticities are in the range of 1.5 as in our benchmark calibration (which is at the high end of the empirical literature), this evidence suggests that relative prices have played a modest role in explaining cyclical import variation, and especially the pronounced swings in imports of the last 15 years.

More broadly, our finding of a fairly modest contribution for the relative price term does not seem likely to hinge on particular features of our adjustment cost specification or calibration, or on the assumed persistence of the relative price shock. The first column of Table 4 extends our graphical analysis by reporting the (the square root) of the mean squared error (MSE) between the data and fitted values for alternative calibrations of the AT specification. The results for our benchmark calibration are shown in the first row. Including the relative price term results in some decline in the MSE relative to the case in which this term is effectively excluded (row 2); however, varying the parameters that affect the response of imports to relative prices (including the trade price elasticity, adjustment cost parameter, and shock persistence) does not yield MSE's much lower than the benchmark. In fact, even when we optimize the adjustment cost and trade price elasticity parameters to minimize the MSE (row 3, which coincides with an ordinary least squares estimator), the implied MSE is only a tad lower than under the benchmark. Overall, our results suggest that a specification in which the real activity variable in the import equation fails to "soak up" most of the pronounced variation in imports will perform relatively poorly in accounting for import behavior.

Figure 1B compares real U.S. nonoil imports to the fitted values of real imports implied by our DT specification (both HP-filtered). The fitted series tracks import demand remarkably well, including during periods involving large cyclical swings in imports (the better fit is also reflected in a lower MSE in Table 4). The improved

\footnotetext{
${ }^{4}$ The fall in import price variability is consistent with a recent literature suggesting a marked decline in the passthrough of exchange rate changes to import prices, e.g., Marazzi, Sheets, and Vigfusson (2005).
} 
fit under this specification is almost wholly attributable to the activity component, as the relative price component is virtually identical to that under the DT specification. ${ }^{5}$ Importantly, the DT activity measure $A_{t}^{D T}$ is nearly as volatile as real imports. Recalling the high weight that investment receives in the DT absorption measure, our evidence suggests that investment swings might play a considerably more prominent role in determining import demand than implied by traditional absorption-based (or output-based) trade models; moreover, the DT specification seems to perform well in accounting for imports even given the imposition of the theoretical constraint of unity on the (DT-based) absorption elasticity.

\section{Simulations}

\subsection{A Foreign Investment Demand Shock}

Figure 3 shows the effects of a rise in foreign investment demand under the two alternative trade specifications. The underlying shock is a highly persistent decline in the foreign capital income tax rate $\tau_{K t}^{*}$, although it can be interpreted more broadly as a shock that boosts the expected return on foreign capital. For each trade specification, the shock is scaled so that the foreign investment rate at its maximum rises 1 percentage point above steady state.

We begin by focusing on the AT specification. To understand the channels through which the foreign investment shock affects the domestic economy, note that the foreign analogue of equation (12) may be written:

$$
\begin{aligned}
\tilde{X}_{t}=\tilde{M}_{t}^{*} & =\tilde{A}_{t}^{*}-\epsilon_{A}\left(\tilde{P}_{M t}^{*}-\tilde{P}_{A t}^{*}\right) \\
& =\left(\frac{C^{*}}{A^{*}}\right) \tilde{C}_{t}^{*}+\left(\frac{I^{*}}{A^{*}}\right) \tilde{I}_{t}^{*}-\epsilon_{A}\left(\tilde{P}_{M t}^{*}-\tilde{P}_{A t}^{*}\right),
\end{aligned}
$$

\footnotetext{
${ }^{5}$ This reflects that the empirical counterparts of the relative price terms, i.e., of $\psi_{t}$ and $\psi_{t}^{D T}$, behave almost identically.
} 
where for simplicity we have abstracted from adjustment costs. Thus, domestic exports rise both because foreign absorption (i.e., $\tilde{A}_{t}^{*}$ ) increases, and because home goods become relatively cheaper in the foreign market. The relative price effect is driven by a decline in the home country's real exchange rate, reflecting that foreign real interest rates rise relative to domestic real interest rates.

Notwithstanding this change in interest rate spreads, domestic real interest rates rise as the export stimulus boosts domestic real GDP, and pushes up price inflation. In turn, higher real rates reduce domestic consumption and investment spending (with the decline in investment particularly pronounced, due to its greater interest sensitivity). Thus, real imports are depressed as the effects of weaker domestic absorption are reinforced by the real exchange rate decline.

Given that pass-through of exchange rate changes to import prices is complete after a couple of quarters in our model, changes in the relative price of imports nearly coincide with the changes in the real exchange rate. With real imports falling 2.5 percent at their trough and the real exchange rate depreciating 1.5 percent over the same interval, nominal imports decline by only 1 percent. Hence, the improvement in the trade balance of about 0.5 percentage point of GDP is mostly explained by the 3 percent increase in real exports.

It is clear from Figure 3 that the qualitative effects of the foreign investment shock on the home country's trade and real exchange rate are identical under the DT specification (using essentially the same logic as described above). Thus, the interesting issue is to explain the larger quantitative effects on exports and the nominal trade balance under the DT specification, and also the somewhat smaller real exchange rate depreciation. Reasoning from the foreign analogue of (14), the foreign activity variable under the DT specification weights the expenditure components by their share in foreign imports, rather than by their share in foreign private absorption (as under the AT specification, recalling equation (16)). Accordingly, foreign investment receives a weight of roughly $3 / 4$ under the DT specification, while only 
about $1 / 4$ under the AT specification.

Given that the underlying shock has much larger stimulative effects on foreign investment than foreign consumption (which actually declines slightly under either trade specification), the effects on home exports arising from the foreign activity channel are much larger under the DT specification. ${ }^{6}$ This accounts for the larger export response shown in Figure 3. Interestingly, the greater export stimulus under the DT specification coming from the activity channel is partly offset by a smaller depreciation of the real exchange rate. Because the foreign shock stimulates domestic external demand to a greater degree, domestic real interest rates rise by more under the DT specification. This reduces the magnitude of real depreciation of the home currency relative to the AT specification.

The larger export improvement under the DT specification translates into a more substantial improvement in the nominal trade balance (of about 0.8 percentage point of GDP, relative to 0.5 percentage point under the AT specification). Thus, a foreign investment shock has a bigger effect on the domestic trade balance under the DT specification than under the AT specification, even while generating a smaller depreciation of the domestic currency.

\subsection{A Foreign Consumption Demand Shock}

Figure 4 displays the effects of a foreign consumption demand shock under both trade specifications. This shock is modeled as a preference shift $\nu_{c t}^{*}$ that has a highly persistent effect on the foreign marginal utility of consumption. The shock is scaled so that the ratio of foreign private consumption to output rises 1 percentage point above steady state at its peak.

Under the AT specification, the foreign consumption shock induces very similar effects on the home country as the foreign investment shock described above: in

\footnotetext{
${ }^{6}$ The foreign activity channel relevant in the domestic export equation is the partial effect of a change in foreign activity holding relative prices constant.
} 
fact, the quantitative effects of each shock are nearly identical, as can be seen by comparing Figure 4 to Figure 3 . The similar quantitative effects reflect that while the foreign consumption and investment shocks have disparate effects on the components of foreign absorption, they have nearly identical implications for total foreign absorption. Given that only total foreign absorption enters as the activity variable in the domestic export equation (equation 16), the stimulus to domestic exports arising from the foreign activity channel is nearly identical in response to either shock; as a consequence, the shocks have similar effects on the real exchange rate, trade balance, and its components.

Returning to Figure 4, it is clear that the foreign consumption shock has considerably different quantitative effects under the DT specification than under the AT specification. In particular, real exports improve by less under the DT specification, real imports fall by more, and the real exchange rate exhibits a more pronounced depreciation. The divergence reflects that the direct stimulus to domestic exports arising from the foreign activity channel is virtually negligible under the DT specification. This is because the foreign consumption shock causes foreign investment to contract, and foreign investment has a high weight of roughly $3 / 4$ in the foreign activity measure in the domestic export equation. Thus, while the foreign activity measure rises 0.8 percent under the AT specification in response to the foreign consumption shock, it rises only 0.1 percent under the DT specification.

With a smaller "direct" stimulus to exports under the DT specification, the foreign consumption shock induces a smaller increase in domestic real interest rates, which in turn helps account for the larger depreciation of the real exchange rate apparent in Figure 4. Accordingly, even though the effects on the nominal trade balance are only slightly smaller under the DT specification, the adjustment of the components is quite different. In particular, the rise in exports under the DT specification is almost wholly attributable to real exchange rate depreciation (rather than stronger foreign activity, as under the AT specification), while the much deeper 
import contraction under the DT specification is also attributable to the larger exchange rate depreciation.

Finally, it is useful to explicitly compare the effects of foreign investment and consumption shocks under the DT specification using Figures 3 and 4 . While we have observed that these shocks have very similar effects under the AT specification, it is clear that under the DT specification that the foreign investment shock exerts a much larger effect on domestic real exports and the trade balance, while implying much less exchange rate depreciation. As our analysis above indicates, this reflects that the foreign investment shock imparts a much larger external stimulus to the domestic economy through a direct activity channel than the foreign consumption shock.

\subsection{A Domestic Investment Demand Shock}

Figure 5 shows the effects of a fall in home investment demand under the two trade specifications. The underlying shock is a highly persistent decline in the domestic capital income tax rate $\tau_{K t}$, and is scaled so that the investment rate decreases 1 percentage point below steady state at its trough.

Under the AT specification, the fall in investment demand induces a decrease in domestic real interest rates, stimulating consumption. With the increase in consumption only partially offsetting lower investment, domestic absorption falls, reducing domestic import demand. The effect of lower domestic absorption on imports is reinforced by a depreciation of the real exchange rate. The real exchange rate depreciation occurs because domestic real interest rates fall by more than foreign rates. Home exports rise both due to the real depreciation, and because foreign interest rate cuts (in response to weak external demand) stimulate foreign absorption.

While the qualitative implications of the shock are similar under the DT specification, there are substantial quantitative differences: notably, the contraction in real imports is much larger under the DT specification, and the trade balance improve- 
ment larger, despite a smaller depreciation of the real exchange rate. As suggested by equation (13), real imports fall by more under the DT specification because imports are mainly driven by variation in domestic investment. Interestingly, because exports drop more sharply in the foreign economy under the DT specification, foreign interest rates fall by more than under the AT specification, which mainly accounts for the smaller depreciation of the (home) real exchange rate under the DT specification. Thus, as in the case of the foreign investment shock, more of the trade adjustment under the DT specification is attributable to an activity rather than to a relative price channel.

\subsection{A Domestic Consumption Demand Shock}

Figure 6 shows the response of key variables to a preference shock $\nu_{c t}$ that temporarily reduces consumption as a share of GDP by 1 percentage point at its trough.

Under the AT specification, the consumption shock induces very similar quantitative effects on the home country as the investment shock just described. Both shocks have commensurate effects on total domestic absorption, which is the activity variable that drives imports in the AT specification; as a consequence, the shocks have nearly the same effects on the real exchange rate, trade balance, and its components.

The effects of the consumption shock under the DT specification are markedly different than under the AT specification, as the former implies a smaller contraction in imports, despite a noticeably larger exchange rate depreciation. The smaller import contraction reflects that the impetus from the activity measure in the domestic import equation is negligible, as domestic investment actually rises somewhat (and receives a high weight under the DT specification). The larger real exchange rate depreciation under the DT specification reflects a much sharper fall in domestic relative to foreign interest rates. Foreign interest rates fall less because the consumption shock exerts a less contractionary impact on foreign exports (which are 
heavily concentrated in investment goods under the DT specification). Thus, given that the foreign country fails to cushion the impact of the shock on the home country by lowering its interest rates as much as under the AT specification (which in that case boosts absorption abroad, and home exports), more of the adjustment must occur through real depreciation of the home currency.

In comparing the effects of the domestic investment and consumption shock under the DT specification, it is clear that the investment shock induces a significantly larger adjustment of the trade balance, exerts larger effects on real imports, and is associated with much less exchange rate depreciation than the consumption shock. The larger effect reflects both that the home country's imports are heavily investment-intensive, and that domestic investment shocks exert comparatively larger effects on the foreign economy (which translates into larger foreign interest rate cuts, and more stimulus to domestic exports).

\subsection{A Technology Shock}

Figure 7 shows the effects of a technology shock that boosts the level of real GDP by 1 percent in the long run. The effects of the shock are qualitatively similar under either trade specification. In particular, because the technology shock pushes up the marginal product of capital, investment increases faster than output. Consumption also rises, though much less than output due to the restraining effect of higher real interest rates. The rise in absorption boosts imports under either trade specification, and causes the trade balance to deteriorate. However, given that the shock has a disproportionately large effect on investment spending, imports exhibit a more pronounced rise under the DT specification, and the trade balance deterioration is somewhat larger. 


\subsection{A Persistent Rise in Foreign Activity}

We conclude with two simulations that involve simple dynamic extensions of the earlier experiments of one-time innovations to foreign investment and consumption. In particular, Figure 8 considers the effects of a sequence of foreign investment innovations that gradually raises the foreign investment share by 1.5 percentage points above baseline (the foreign investment innovations are identified with negative innovations to the foreign capital tax rate, as described in the first simulation). The 1.5 percentage point rise in the investment rate is calibrated to reverse the estimated decline in the investment rate that has occurred in major U.S. OECD trading partners since the late 1990s. We compare the implications of a rise in foreign investment of this magnitude to the effects that would arise if the foreign consumption rate increased by a similar percentage of GDP. Both simulations are conducted using our preferred DT specification.

As suggested by our analysis of the foreign investment and consumption shocks above, the foreign investment shock exerts a considerably larger effect on the U.S. trade balance than the foreign consumption shock, even while implying a much smaller depreciation of the real exchange rate. Thus, while the trade balance improves by over 1.0 percentage point of GDP after 5 years and the real exchange rate depreciates less than one percent, the trade balance improves only 0.6 percentage point in response to the foreign consumption shock, while the real exchange rate depreciates over 4 percent. Moreover, while the foreign investment shock induces a sizeable response of real exports and comparatively small import contraction, the foreign consumption shock is associated with a much weaker rise in exports, and larger import decline. 


\section{Conclusion}

In this paper, we have used simulations of an SDGE model to show that taking account of the expenditure composition of U.S. trade yields implications for the responses of trade flows to shocks that are markedly different from those of a "standard" framework that abstracts from such compositional differences. Overall, our preferred trade specification implies that investment shocks, originating from either foreign or domestic sources, may serve as a strong catalyst for trade balance adjustment; and moreover, such adjustment may be consistent with a fairly stable real exchange value of the dollar. From a policy perspective, our results suggest that while policy changes that boost foreign investment might improve the U.S. trade balance significantly through an export channel, reforms oriented at stimulating foreign consumption would exert less of a corrective effect on the trade balance, and would be associated with a much larger decline in the real dollar. 


\section{References}

Anderson, G. and G. Moore (1985). A Linear Algebraic Procedure for Solving Linear Perfect Foresight Models. Economic Letters 17, 247-52.

Backus, D. K., P. J. Kehoe, and F. E. Kydland (1994). Dynamics of the Trade Balance and the Terms of Trade: The J-Curve? American Economic Review 84, 84-103.

Blanchard, O. J. and C. M. Kahn (1980). The Solution of Linear Difference Models under Rational Expectations. Econometrica 48(5), 1305-11.

Chari, V., P. Kehoe, and E. McGrattan (2002). Can Sticky Price Models Generate Volatile and Persistent Real Exchange Rates? Review of Economic Studies 69, $533-563$.

Christiano, L. J., M. Eichenbaum, and C. L. Evans (2005). Nominal Rigidities and the Dynamic Effects of a Shock to Monetary Policy. Journal of Political Economy 113(1), 1-45.

Croke, H., S. Kamin, and S. Leduc (2005). Financial Market Developments and Economic Activity during Current Account Adjustments in Industrial Economies. FRB International Finance and Discussion Papers No. 827.

Erceg, C. J., L. Guerrieri, and C. Gust (2006). SIGMA: A New Open Economy Model for Policy Analysis. International Journal of Central Banking, 1-50.

Freund, C. (2000). Current Account Adjustment in Industrial Countries. FRB International Finance and Discussion Papers No. 693.

Hooper, P., K. Johnson, and J. Marquez (2000). Trade Elasticities for the G-7 Countries. Princeton Studies in International Economics.

Laxton, D. and P. Pesenti (2003). Monetary rules for small, open, emerging economies. Journal of Monetary Economics 50, 1109-1146.

Marazzi, M., N. Sheets, and R. J. Vigfusson (2005). Exchange Rate Pass-Through to U.S. Import Prices: Some New Evidence. FRB International Finance and 
Discussion Papers No. 833.

McDaniel, C. and E. Balistreri (2003). A Review of Armington Trade Substitution Elasticities. Integration and Trade Journal 7, 161-73.

Orphanides, A. and V. Wieland (1998). Price Stability and Monetary Policy Ineffectiveness when Nominal Interest Rates are Bounded at Zero. Finance and Economics Discussion Paper No. 98-35, Washington DC: Board of Governors of the Federal Reserve System.

Smets, F. and R. Wouters (2003). An Estimated Dynamic Stochastic General Equilibrium Model of the Euro Area. Journal of the European Economic Association 1, 1124-1175.

Turnovsky, S. J. (1985). Domestic and Foreign Disturbances in an Optimizing Model of Exchange-Rate Determination. Journal of International Money and Finance 4 (1), 151-71. 
Table 1: Composition of U.S. Non-energy Imports in 2004

\begin{tabular}{|l|r|r|}
\hline TOTAL NON-ENERGY IMPORTS & Billions of \$US & $\begin{array}{r}\text { Percent } \\
\text { of imports }\end{array}$ \\
\hline 1. Consumer Nondurable Goods & $\mathbf{1 2 0 9}$ & $\mathbf{1 0 0}$ \\
a. Foods, feeds, beverages & $\mathbf{3 3 5}$ & 62 \\
b. Manufactured consumer goods & 174 & \\
c. Nonmanufactured consumer goods & 18 & \\
d. Non-energy industrial supplies & & \\
used in nondurable consumer goods & 81 & \\
2. Consumer Durable Goods & $\mathbf{3 8 9}$ & $\mathbf{3 2}$ \\
a. Automotive less trucks, buses & 208 & \\
b. Manufactured durables & 181 & \\
3. Capital Goods & $\mathbf{3 6 4}$ & $\mathbf{3 0}$ \\
a. Non-auto capital goods & 343 & \\
b. Trucks, buses, etc. & 21 & \\
4. Non-energy industrial supplies & & $\mathbf{1 0}$ \\
used in producing durables & $\mathbf{1 2 1}$ & \\
\hline
\end{tabular}


Table 2: Composition of U.S. Non-energy Exports in 2004

\begin{tabular}{|l|r|r|}
\hline TOTAL NON-ENERGY EXPORTS & Billions of \$US & $\begin{array}{r}\text { Percent } \\
\text { of exports }\end{array}$ \\
\hline 1. Consumer Nondurable Goods & $\mathbf{7 5 9}$ & $\mathbf{1 0 0}$ \\
a. Foods, feeds, beverages & $\mathbf{1 8 6}$ & $\mathbf{2 5}$ \\
b. Manufactured consumer goods & 49 & \\
c. Nonmanufactured consumer goods & 8 & \\
d. Non-energy industrial supplies & & \\
used in nondurable consumer goods & 72 & \\
2. Consumer Durable Goods & $\mathbf{1 2 3}$ & $\mathbf{1 6}$ \\
a. Automotive less trucks, buses & 77 & \\
b. Manufactured durables & 46 & \\
3. Capital Goods & $\mathbf{3 4 3}$ & $\mathbf{4 5}$ \\
a. Non-auto capital goods & 331 & \\
b. Trucks, buses, etc. & 12 & \\
4. Non-energy industrial supplies & & $\mathbf{1 4}$ \\
used in producing durables & $\mathbf{1 0 7}$ & $\mathbf{1 4}$ \\
\hline
\end{tabular}


Table 3: Calibration

\begin{tabular}{|c|c|c|c|}
\hline Parameter & Used to Determine & Parameter & Used to Determine \\
\hline \multicolumn{4}{|c|}{ Parameters governing households' behavior } \\
\hline$\beta=0.997$ & discount factor & $\chi=10$ & labor supply elasticity ${ }^{a}$ \\
\hline$\sigma=2$ & consumption elasticity $^{a}$ & $\varkappa=0.8$ & consumption habits \\
\hline$\varsigma=0.5$ & frac. of HM households & $\phi_{I}=3$ & investment adj. cost \\
\hline$\phi_{b}=0.001$ & financial intermediation cost & $\bar{g}=18$ & govt. spending share \\
\hline \multicolumn{4}{|c|}{ Parameters governing firms' behavior } \\
\hline$g_{z}=1.0037$ & rate of technological growth & $\delta=0.025$ & depreciation rate \\
\hline$\theta_{p}=0.20$ & price markup & $\theta_{w}=0.20$ & wage markup \\
\hline$\xi_{p}=0.75$ & avg. duration of domestic price & $\xi_{w}=0.75$ & avg. duration of wage \\
\hline$\xi_{p, x}=0.5$ & avg. duration of export price & $\rho=-2$ & K-L substitution elasticity \\
\hline \multicolumn{4}{|c|}{ Parameters governing monetary policy } \\
\hline $\begin{array}{l}\gamma_{\pi}=0.6 \\
\gamma_{i}=0.8\end{array}$ & $\begin{array}{l}\text { infl. target elasticity } \\
\text { interest rate smoothing }\end{array}$ & $\gamma_{y}=0.28$ & output growth elasticity \\
\hline \multicolumn{4}{|c|}{ Parameters governing fiscal policy } \\
\hline $\begin{array}{c}\nu_{0}=1 \\
\nu_{2}=0.0001\end{array}$ & $\begin{array}{l}\text { tax rate smoothing } \\
\text { debt growth elasticity }\end{array}$ & $\begin{array}{c}\nu_{1}=0.1 \\
b_{G}=0\end{array}$ & $\begin{array}{l}\text { debt target elasticity } \\
\text { target debt-to-GDP ratio }\end{array}$ \\
\hline \multicolumn{4}{|c|}{ Parameters governing trade } \\
\hline$\zeta_{0}=1$ & home population size & $\zeta_{0}^{*}=3$ & foreign population size $\mathrm{e}^{b}$ \\
\hline$\omega_{A}=0.15$ & import/absorption (AT spec.) & $\rho_{A}=2$ & import price el. (AT spec.) \\
\hline$\varphi_{M_{A}}=15$ & import adj. cost (AT spec.) & & \\
\hline$\omega_{C}=0.052$ & cons. import/cons. (DT spec.) & $\omega_{I}=0.36$ & inv. import/inv. (DT spec.) \\
\hline$\rho_{C}=2$ & cons. import price el. (DT spec.) & $\rho_{I}=2$ & inv. import price el. (DT spec.) \\
\hline$\varphi_{M_{C}}=15$ & cons. import adj. cost (DT spec.) & $\varphi_{M_{C}}=15$ & inv. import adj. cost (DT spec.) \\
\hline
\end{tabular}

${ }^{a}$ The long-run intertemporal elasticity of substitution in consumption is $1 / \sigma=0.5$, while the Frisch elasticity is $2 / \chi=0.2$.

${ }^{b}$ In order to ensure balance trade in steady state, the import shares for the foreign country are scaled down using the foreign population size. All remaining parameters are set at the same value as for the home country. 
Table 4: Mean Squared Error of Predicted Imports (1975-2005) $)^{a, b}$

\begin{tabular}{|l|c|c|}
\hline Experiment & AT Specification & DT Specification \\
\hline 1. Benchmark Calibration $\left(\epsilon_{A}=1.5, \varphi_{M_{A}}=15, \rho_{\psi}=0.9\right)$ & 2.62 & 2.13 \\
2. Activity Measure Only & 3.07 & 2.45 \\
3. Minimized MSE & 2.53 & 2.11 \\
4. Alternative Trade-Price Elasticity ${ }^{d}$ & & \\
$\epsilon_{A}=1$ & 2.68 & 2.11 \\
$\epsilon_{A}=3$ & 2.67 & 2.37 \\
5. Alternative Adjustment Cost Parameter & \\
$\varphi_{M_{A}}=5$ & & 2.34 \\
$\varphi_{M_{A}}=30$ & 2.98 & 2.14 \\
6. Alternative Relative Import Price Persistence & \\
$\rho_{\psi}=0.75$ & 2.59 & \\
$\rho_{\psi}=0.999$ & & 2.12 \\
\hline
\end{tabular}

${ }^{a}$ Entries report the square root of the mean squared error.

${ }^{b}$ AT and DT specifications refer to absorption-based and disaggregated trade specifications implied by equations (12) and (13), respectively.

${ }^{c}$ In this case, $\rho_{\psi}=0.9$ and the parameters $\epsilon_{A}$ and $\varphi_{M_{A}}$ are chosen to minimize the mean-squared error. For the AT specification, $\epsilon_{A}=3.05$ and $\varphi_{M_{A}}=28.44$, and for the DT specification, $\epsilon_{A}=1.08$ and $\varphi_{M_{A}}=15.00$. $d$ The parameter values are the same as in the benchmark calibration except for the alternative parameter under consideration. 
Figure 1: U.S. Real Imports of Goods and Alternative Activity Measures Figure 1A: AT Specification

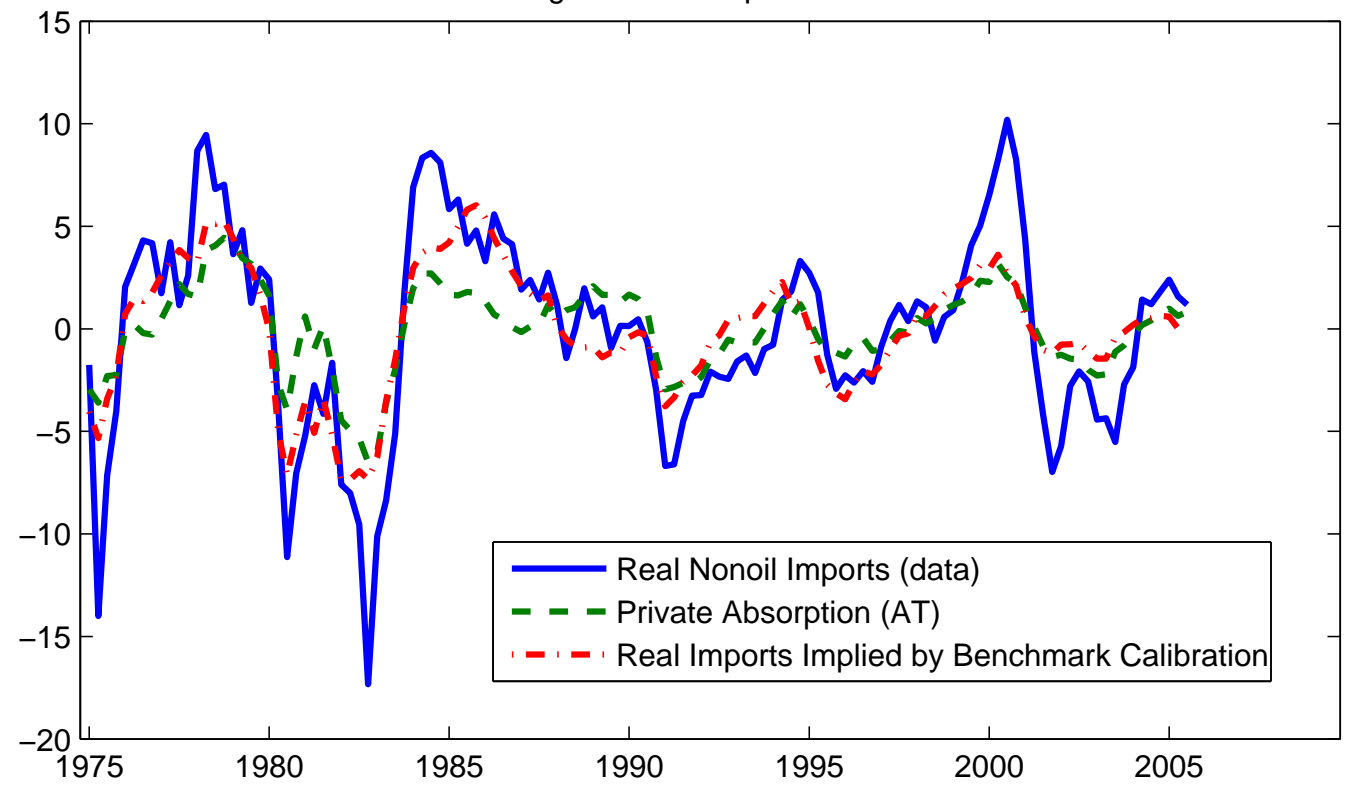

Figure 1B: DT Specification

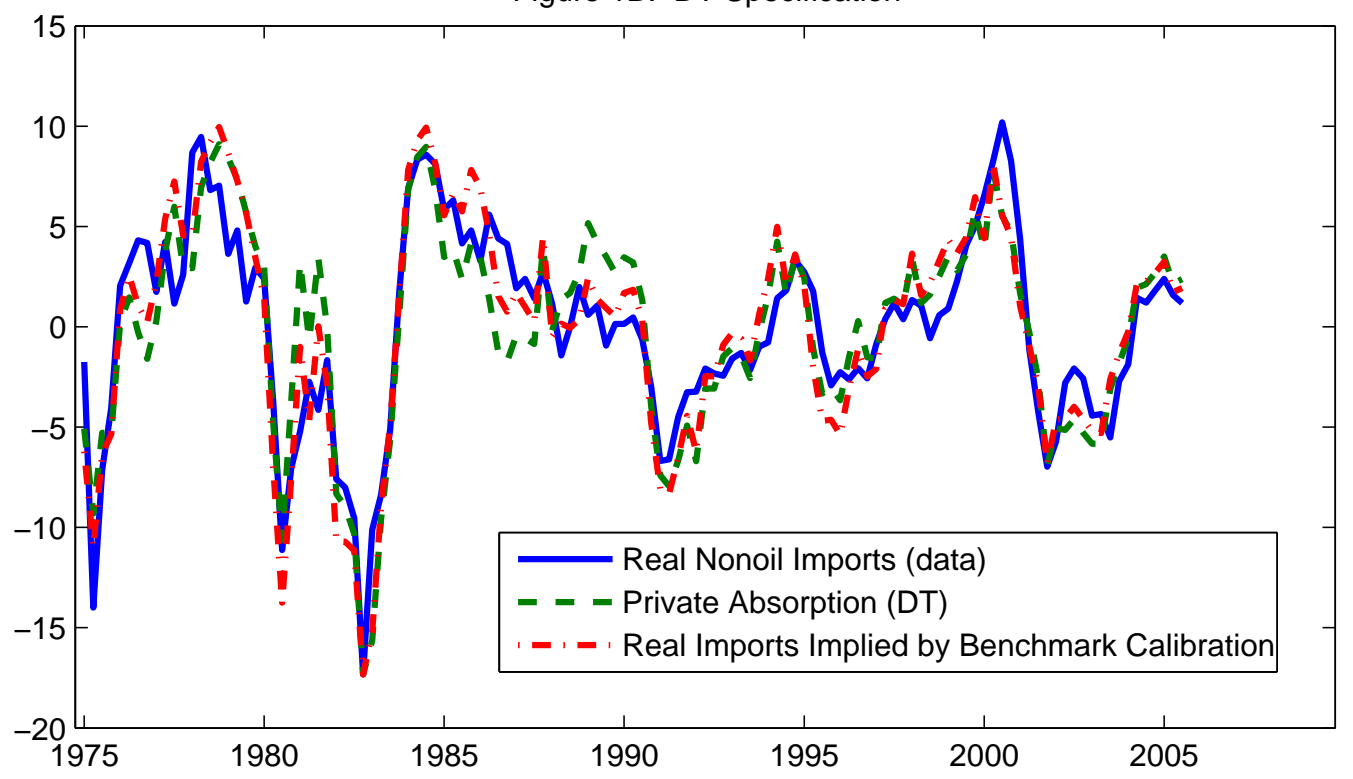


Figure 2: Real Imports and the Relative Price of Imports

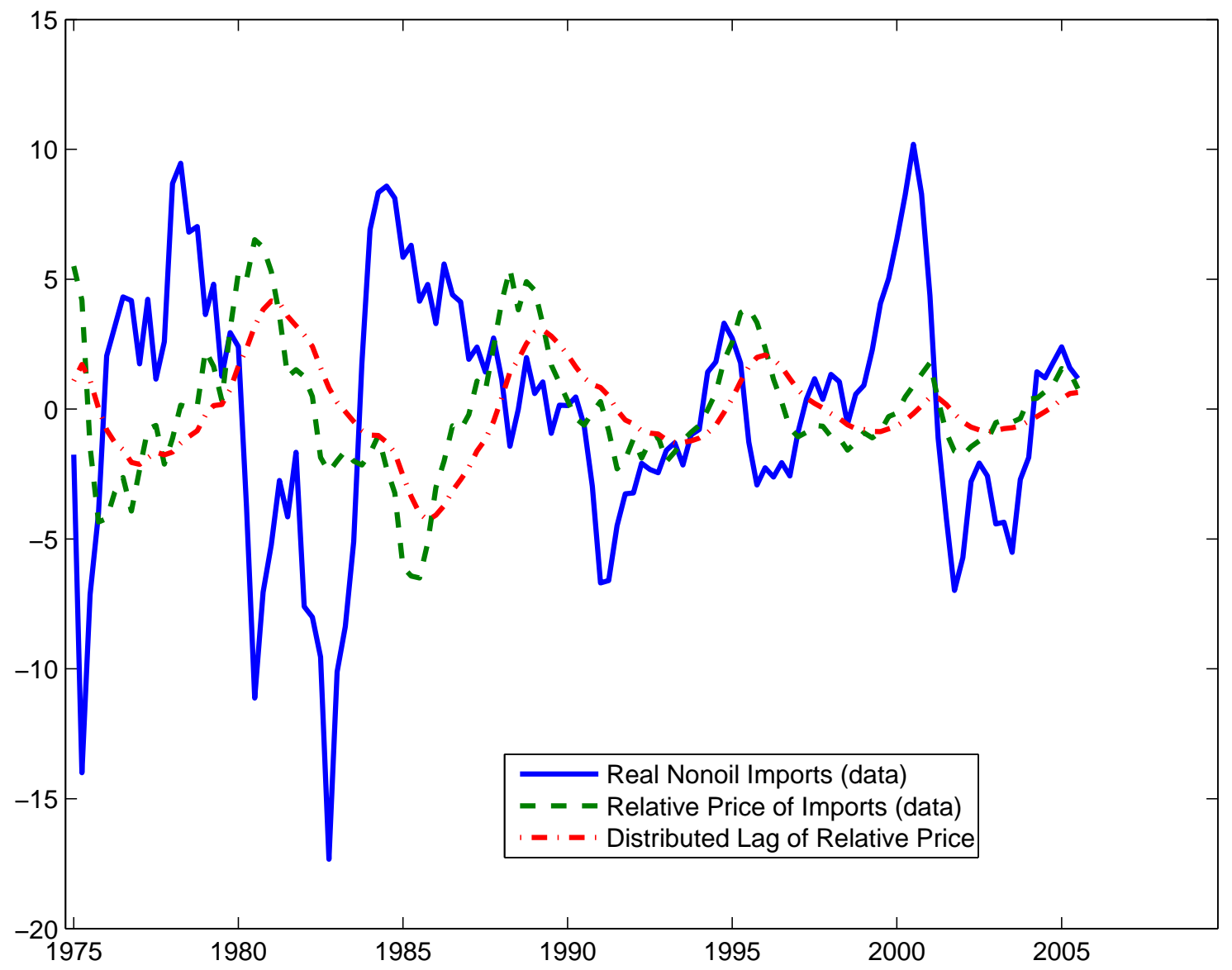


Figure 3: A Foreign Investment Demand Shock
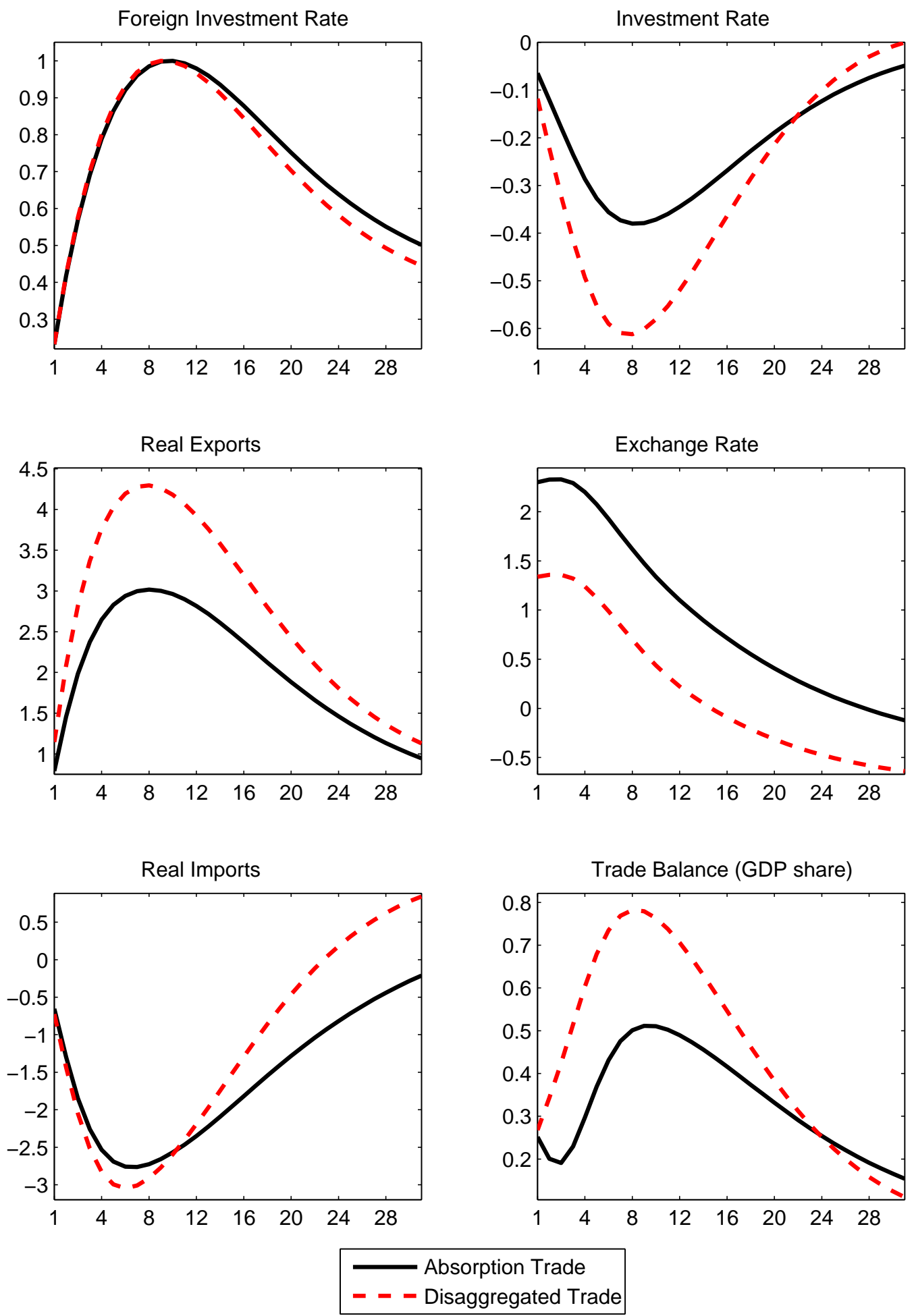
Figure 4: A Foreign Consumption Demand Shock

Foreign Consumption Rate
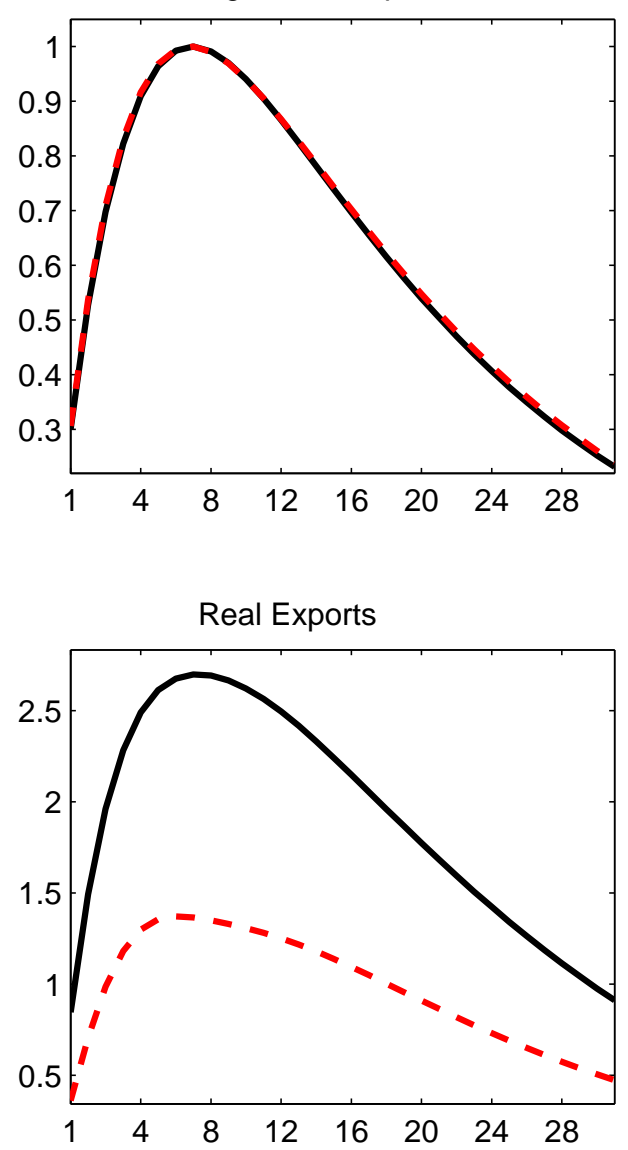

Real Imports

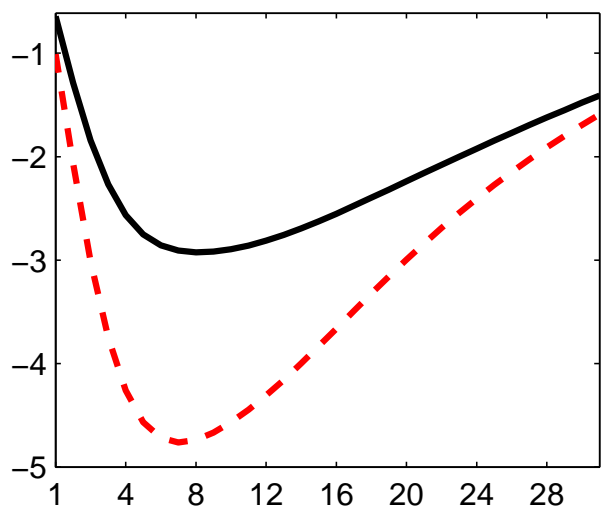

Investment Rate
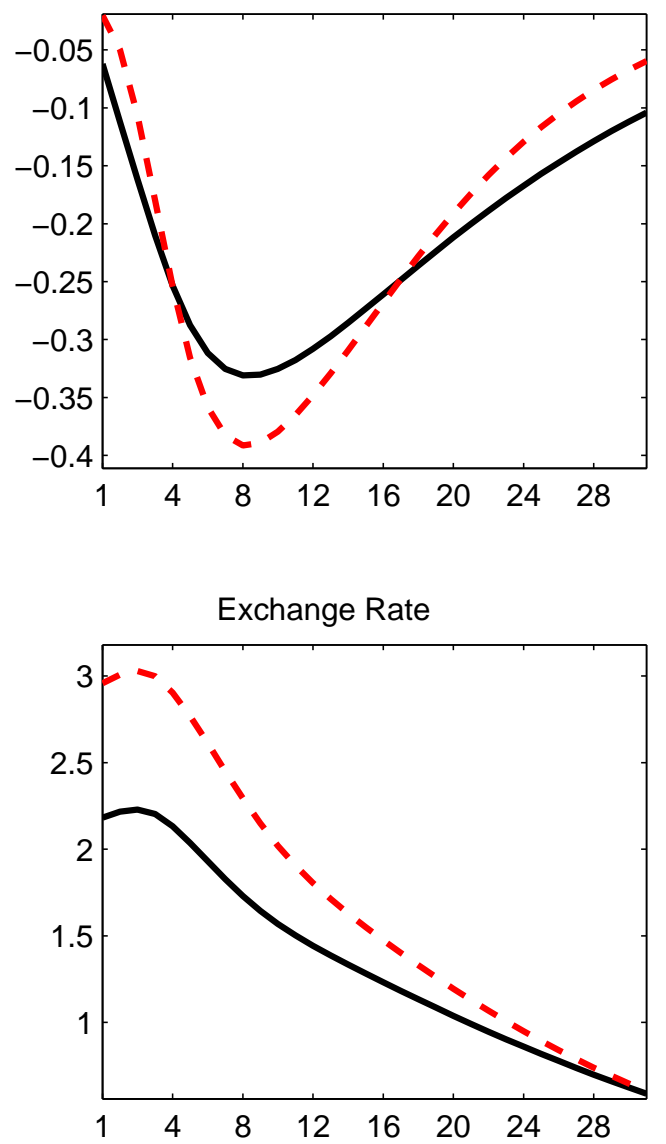

Trade Balance (GDP share)

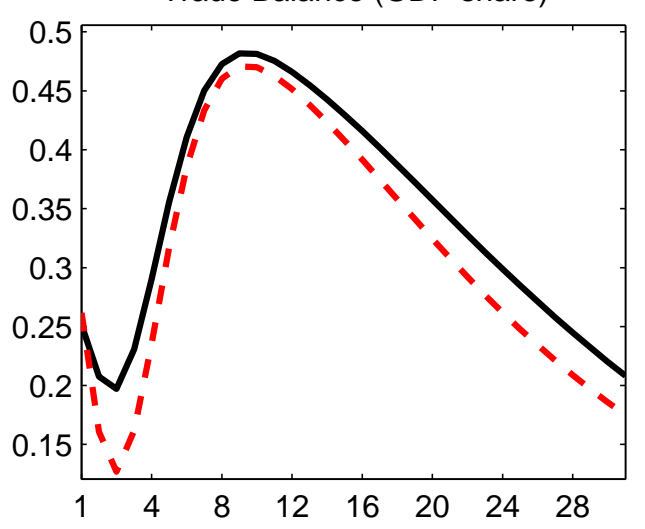

Absorption Trade

- - - Disaggregated Trade 
Figure 5: A Domestic Investment Demand Shock
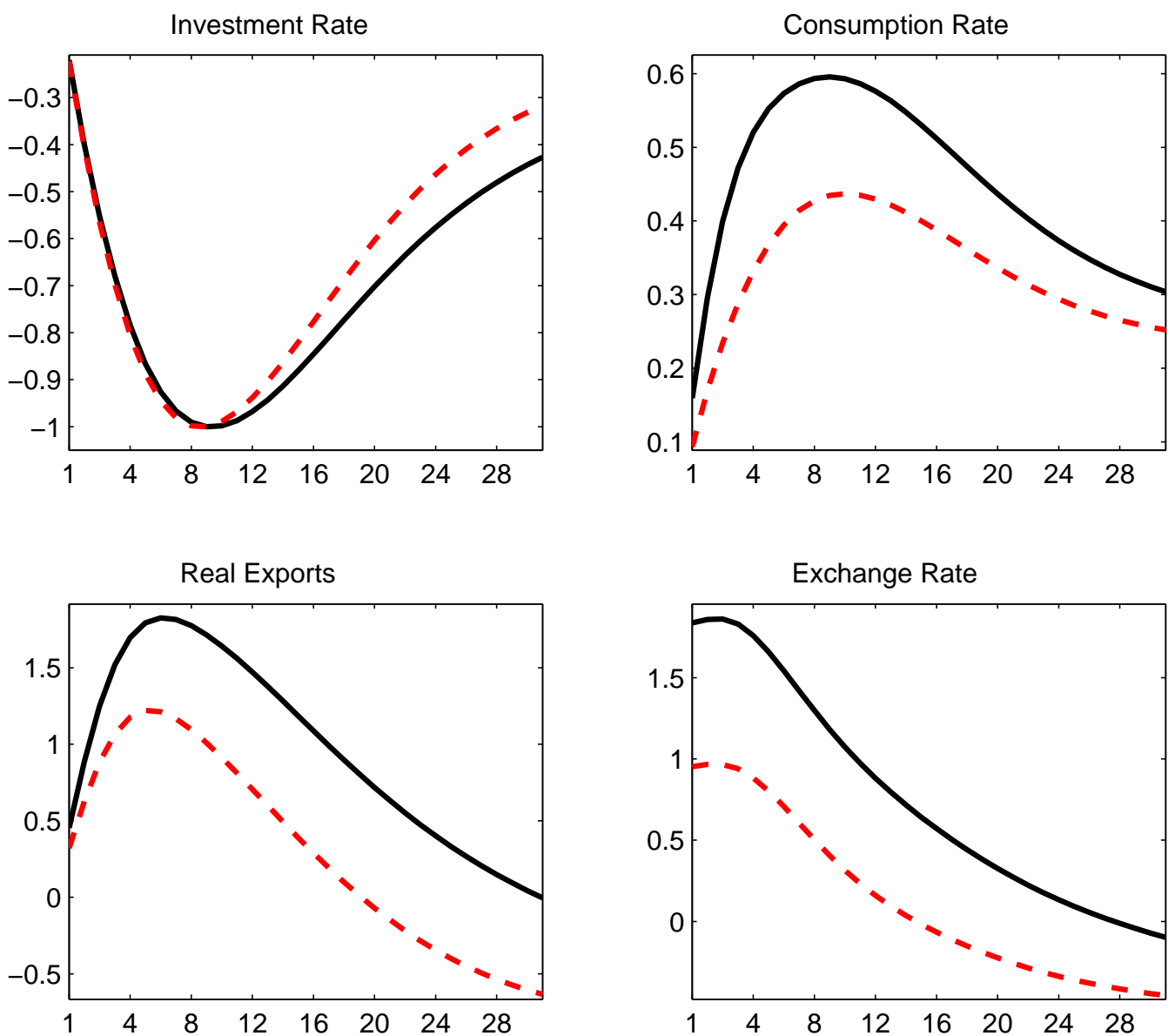

Real Imports
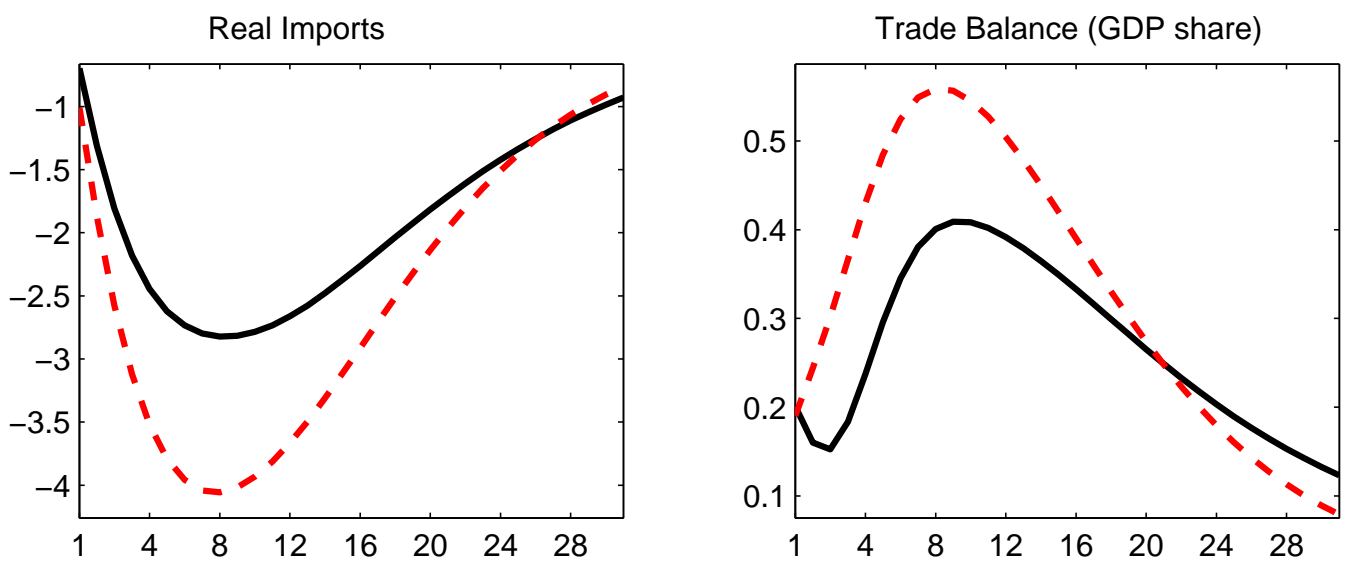

Absorption Trade

Disaggregated Trade 
Figure 6: A Domestic Consumption Demand Shock

Investment Rate
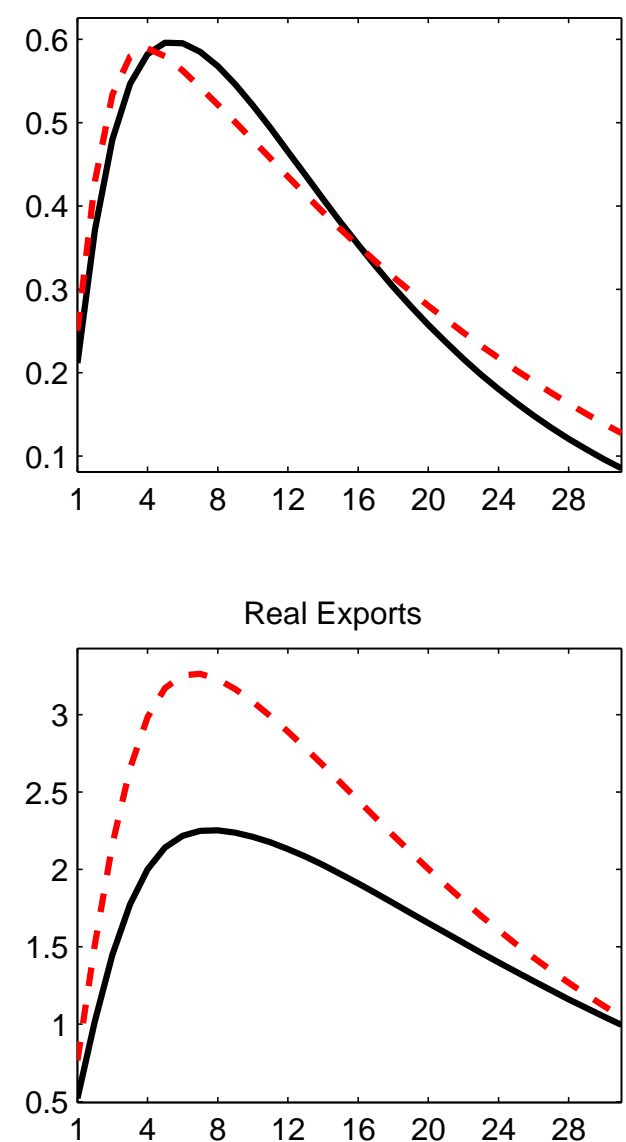

Real Imports

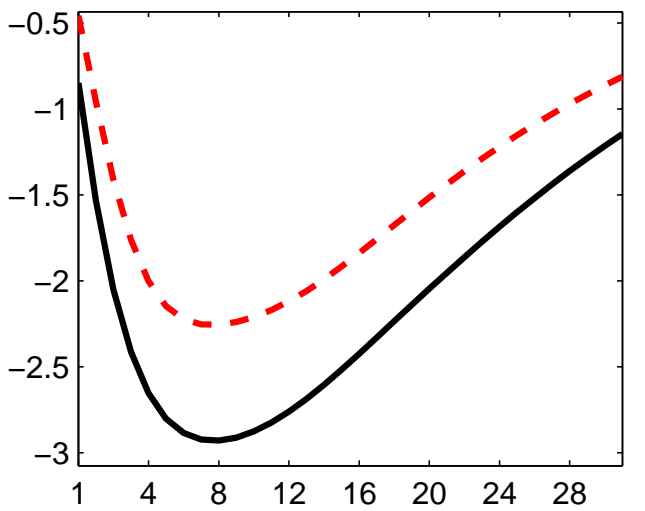

Consumption Rate

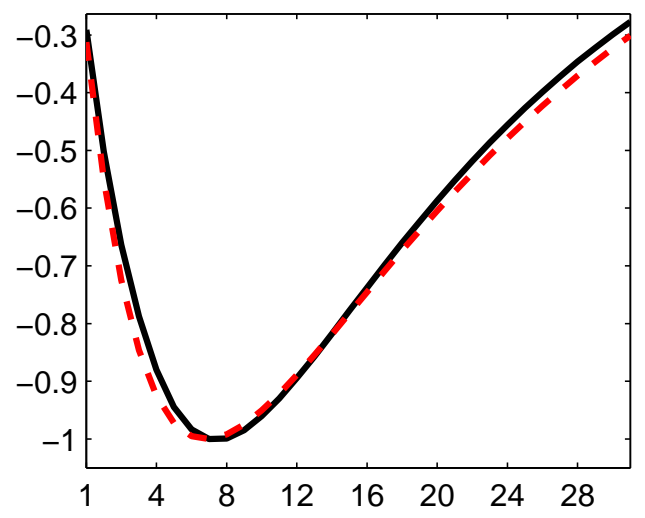

Exchange Rate

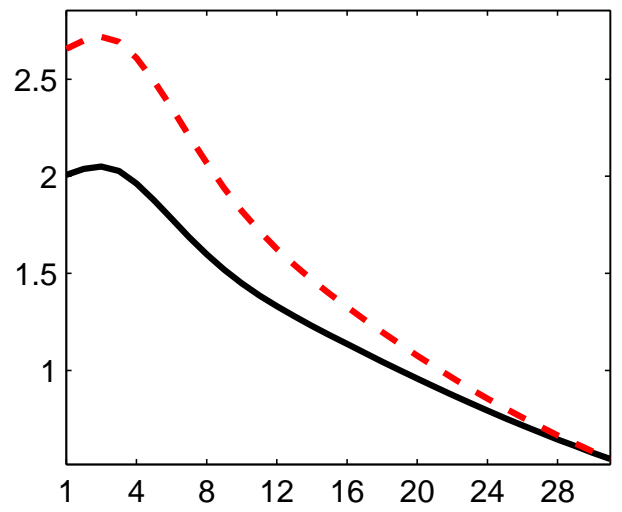

Trade Balance

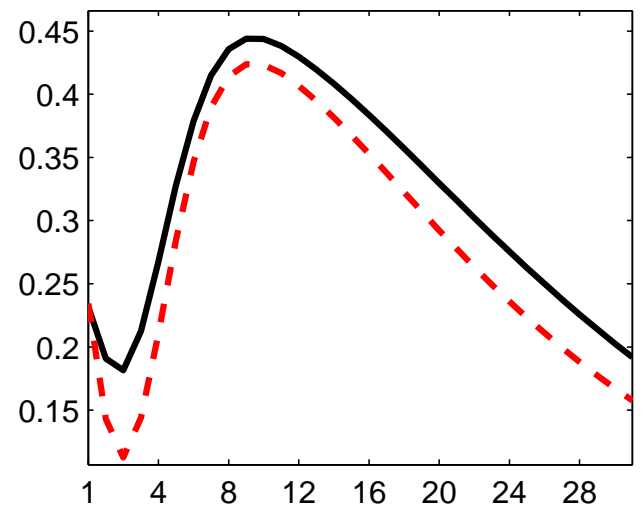

Absorption Trade

- - - Disaggregated Trade 
Figure 7: A Technology Shock that Boosts Real GDP by 1\% in the Long Run

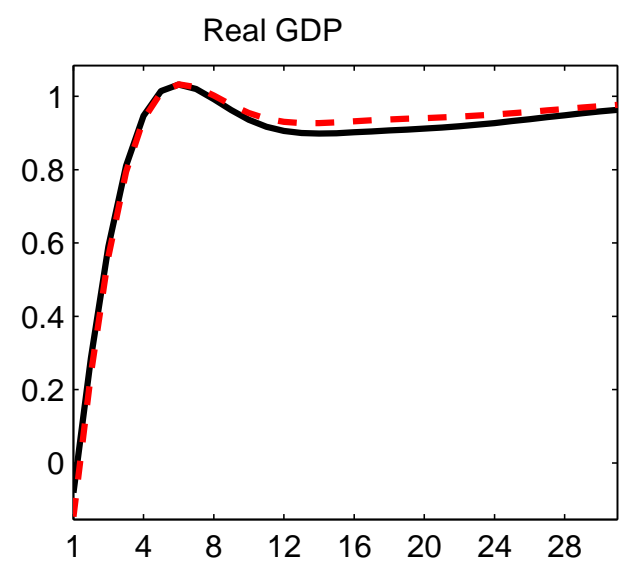

Real Investment
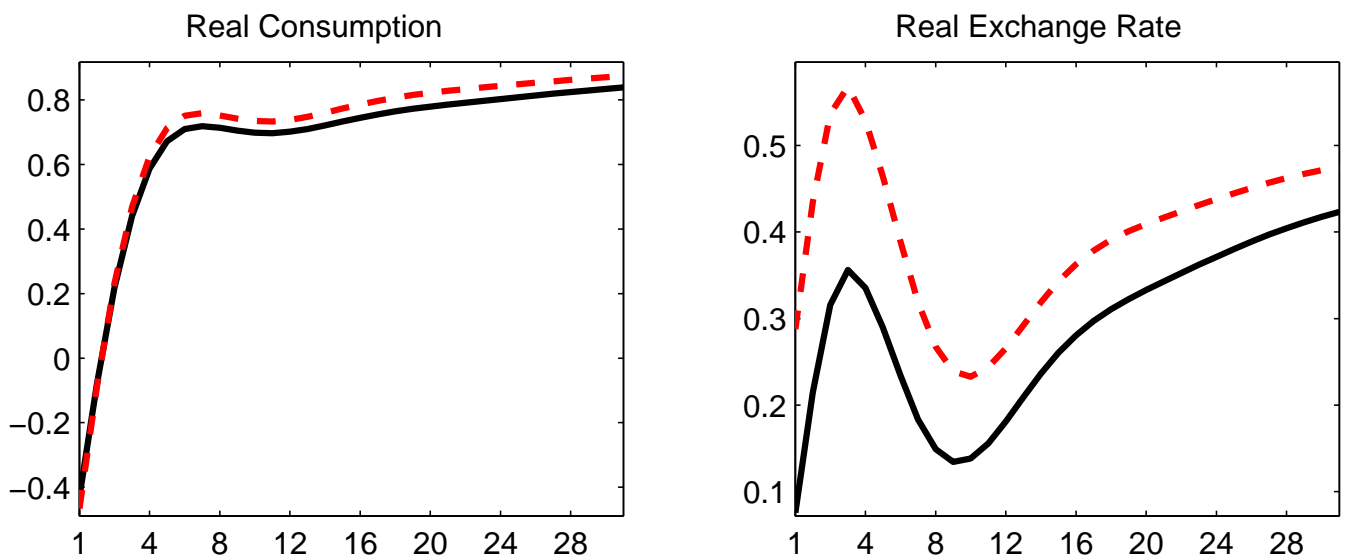

Real Imports

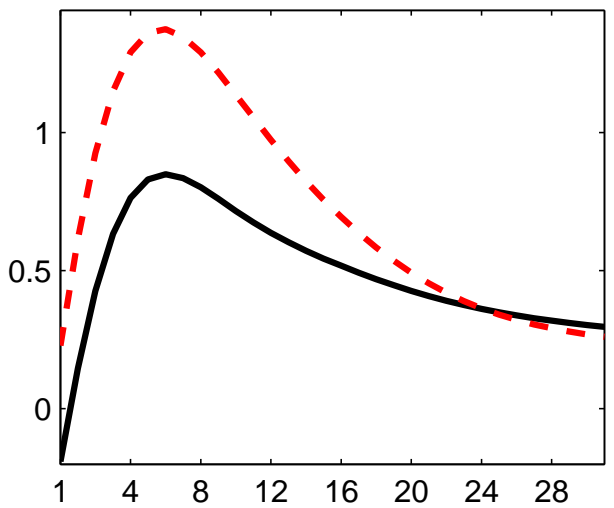

Trade Balance (GDP share)

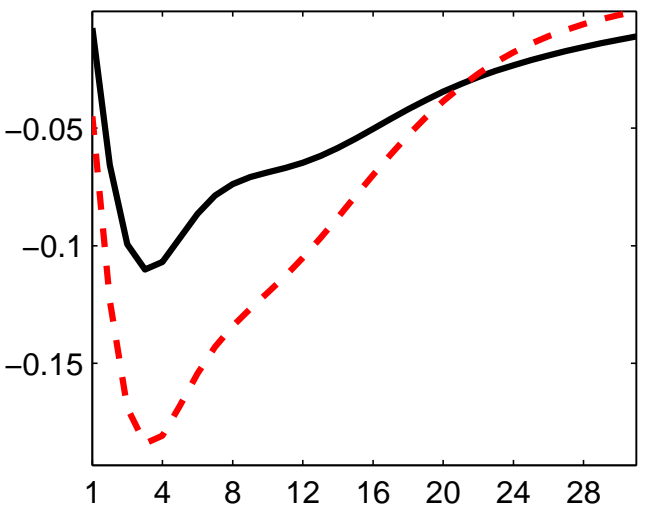

- Absorption Trade
- - Disaggregated Trade 
Figure 8: A Persistent Increase in Foreign Demand (Disaggregated Trade Specification)

Foreign Investment Rate

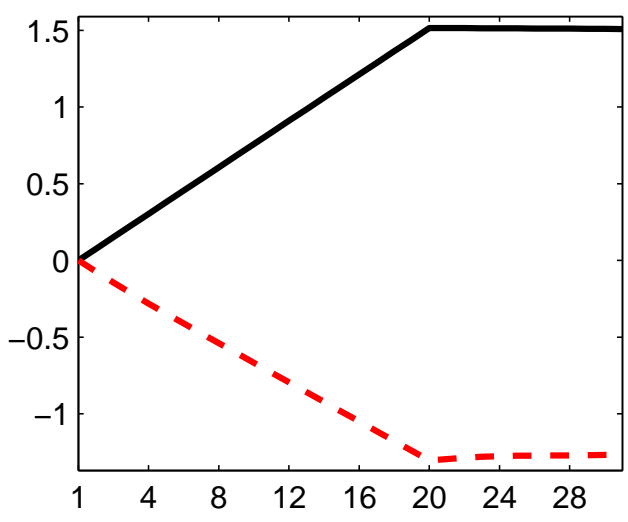

Real Exports

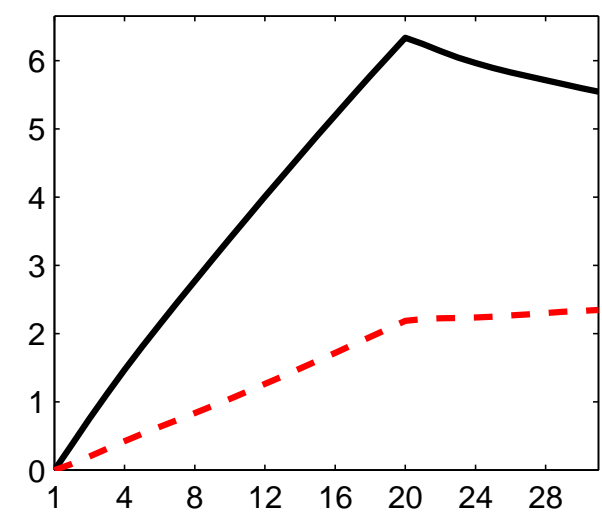

Real Imports

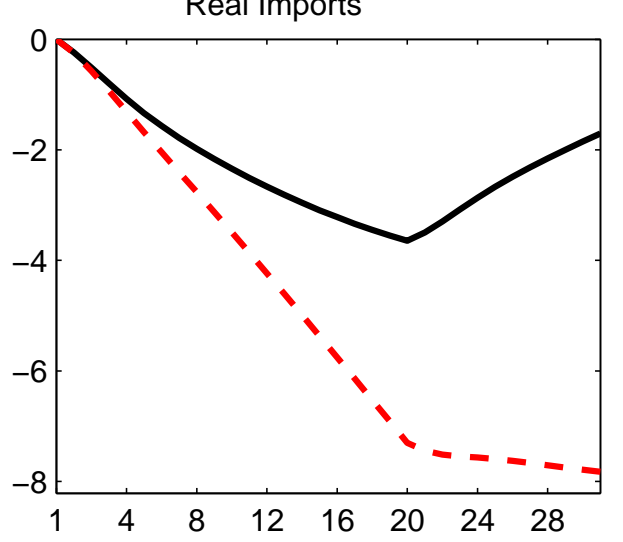

Investment Rate
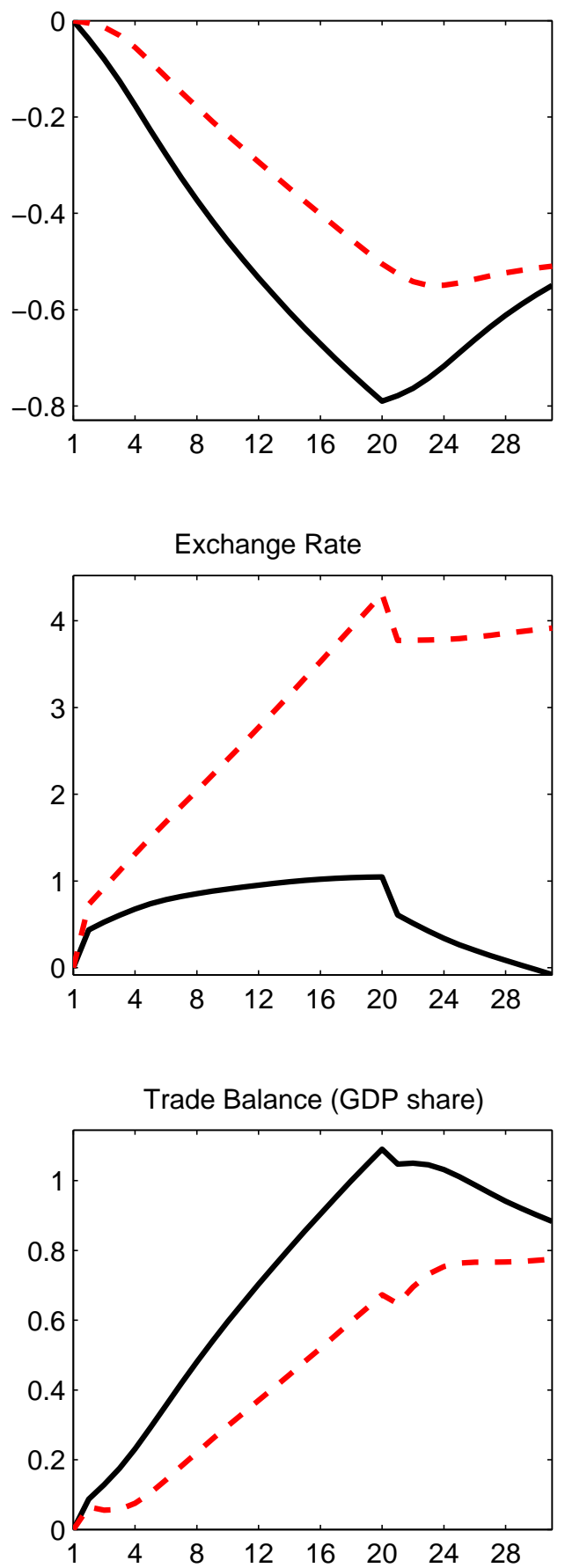

Investment Shock

Consumption Shock 